\title{
Eradicating Al-Qur'an Illiteracy of Prospective Primary School Teachers
}

\author{
Tedi Supriyadi $\otimes_{1}$, J Julia², Prana Dwija Iswara ${ }^{3}$ \& Ani Nur Aeni ${ }^{4}$ \\ 1 Primary School Teacher Physical Education Study, Universitas Pendidikan Indonesia, Bandung, \\ Indonesia \\ 2,3,4 Primary School Teacher Education Study, Universitas Pendidikan Indonesia, Bandung, Indonesia \\ $\bowtie$ tedisupriyadi@upi.edu
}

\begin{abstract}
Lack of students' abilities in reading Al-Qur'an hampers the learning process of Islamic Religious Education (PAl - Pendidikan Agama Islam) in universities. Ironically, this fundamentalism has not been able to be resolved at the previous level of education. Various methods of reading Al-Qur'an have been compiled, but in fact, there are still many students who have not been able to read Al-Qur'an. Hence, this research aims at analyzing the implementation of the TAHQIQ learning model in order to improve Al-Qur'an reading skills. This research employed the action research method. The research subjects were 360 prospective primary school teachers in one of the universities in Sumedang Regency, consisting of 130 male and 240 female prospective teachers. This research revealed that the TAHQIQ learning model was able to improve the students' abilities in reading Al-Qur'an to reach the level of Jayyid in 12 meetings. Therefore, it can be concluded that the TAHQIQ learning model was able to eradicate students who were Al-Qur'an illiterate.
\end{abstract}

Keywords: Al-Qur'an, learning model, illiteracy, Islamic Religious Education, TAHQIQ

How to Cite: Supriyadi, T., Julia, J., Iswara, P. D., \& Aeni, A. N. (2019). Eradicating Al-Qur'an Illiteracy of Prospective Primary School Teachers. Mimbar Sekolah Dasar, 6(2), 219-238. doi:10.17509/mimbarsd.v6i2.16583

INTRODUCTION Although Indonesia is not an Islamic country, but it has the largest Muslim population in the world, with approximately 252.2 million Muslims in 2015 , according to the Indonesian Central Bureau of Statistics (BPS - Badan Pusat Statistik). Arifin (2017) in daily Pikiran Rakyat indicated that $54 \%$ of the population of Indonesian Muslims was included in Muslims who were illiterate in reading AlQur'an. In other words, there was only $46 \%$ of the population of Indonesian Muslims who were able to read Al-Qur'an. This result was in line with the research results of Institut IImu Al-Qur'an in daily Republika, which revealed that there were $65 \%$ of Indonesia Muslims who were still Al-Qur'an illiterate. The data was only measured by whether or not they were able to read AlQur'an.

If the population of Indonesian Muslims is regrouped based on the category of those who do not understand the contents of Al-Qur'an, the numbers will certainly be greater, since it is believed that they will not be able to understand Al-Qur'an, if they cannot read it. In addition, when they do not understand the contents of AlQur'an, they cannot practice and make Al-Qur'an as their life guidance. Therefore, 
Tedi Supriyadi, J. Julia, Prana Dwija Iswara \& Ani Nur Aeni, Eradicating Al-Qur'an Illiteracy...

thus issue must not be tolerated, thus real efforts are needed to eradicate Al-Qur'an illiteracy in Indonesia.

In the curriculum at each level of education, the subject of Islamic Religious Education (PAl - Pendidikan Agama Islam) are included from the level of primary school (SD - Sekolah Dasar) to senior high school (SMA - Sekolah Menengah Atas) and even at the college level. During 12 years of studying the PAl subject from SD to SMA, at least it is able to become a very strategic asset for the nation to resolve the issue of the high rate of Al Qur'an illiteracy.

At the college level, Supriyadi \& Julia (2019) found that the issue of Al-Qur'an illiteracy still emerges with a quite fantastic rate, which could be considered as the impact of the learning process at the previous levels. The research findings revealed that there were only 10 out of 100 students who were Al-Qur'an literate, which indicated that the ratio between students who were Al-Qur'an literate and who Al-Qur'an illiterate was 1:10. The impact of lack of students' ability in reading Al-Qur'an affected them not to be close to Al-Qur'an. Therefore, if they did not close to Al-Qur'an, they would not touch it, and if they did not touch it, they would not read Al-Qur'an; even they would not listen to it.

In the learning context, lack of students' abilities in reading Al-Qur'an hampers the achievement of the PAl learning objectives. This is in accordance with the experience of researchers as PAl lecturers when exploring the values and messages of Al-Qur'an in the learning process. They believe that Al-Qur'an reading ability should be mastered before the students comprehend and dig deeper the values of the Al-Qur'an. PAl at the college level does not only solve the problem of reading the beginning of Al-Qur'an, but it has been included in the implementation of the value of Al-Qur'an. Moreover, this case will be achieved if the initial stage in understanding and implementing AlQur'an has been owned, which is the AlQur'an reading ability.

Nowadays, there are many efforts that have been conducted by various parties to resolve the Al-Qur'an's illiteracy in Indonesia. Various methods have been compiled to improve the ability in $\mathrm{Al}$ Qur'an reading in Indonesia. Sophya and Saipul Mujab (2014) state that there are eight methods of Al-Qur'an reading used in Indonesia from time to time, namely the methods of Baghdadiyah, An-Nahdhiyah, Jibril, lara', Qiro'ati, Al Barqy, Tilawati and Dirosa (Dirasah Orang Dewasa)

The study of these eight methods had been widely discussed, for example, the research conducted by Syaifullah, (2017) that compared the methods of AnNahdliyah with laro'. The results showed that there was a difference in the AlQur'an reading ability between those who applied the methods of an-Nahdliyah and Iaro'. Srijatun (2017) studied the implementation of Al-Qu'ran literacy 
learning using the lqro' method, and compared it with the Tartil method for Early Childhood conducted in one Islamic Kindergarten (RA, Raudhatul Athfal) in Slawi, Tegal Regency, Central Java. The results showed that the ability to recognize hijaiyyah letters in early childhood using the laro' method improved faster than using the Tartil method. Yahya (2010) proposed a method of reading Al-Qur'an, named bil hikmah method. This method was examined by Nurzaman (2014) with the subjects of early childhood. The results revealed that the method of bil hikmah had a significant effect on the improvement of the Al-Qur'an reading ability in a relatively short time.

In addition to exploring several results of the implementation of the learning methods of reading Al-Qu'ran, searches related to the use of media in the learning to read Al-Qur'an were conducted. A research conducted by Mar'i, (2018) about the use of multimedia program in teaching recitation of Al-Qur'an among eighth grade students in light of their selfefficacy and its effectiveness of learning motivation revealed that there was an increase in students' motivation to learn AlQur'an. Furthermore, Abdou \& Rashwan (2014) examined Computer Aided Language Learning (CALL), which is the development of Al-Qur'an recitations practicing system with the aid of the computer to detect errors in reading AlQur'an, and to improve the accuracy of error detection.
Based on several studies above, it seems that there has not been a research that focuses on eradicating Al-Qur'an illiteracy that involved university students as research subjects. Most of the studies related to the implementation of those seven methods, namely the methods of Baghdadiyah, An-Nahdhiyah, Jibril, Iqra', Qiro'ati, Al Barqy and Tilawati, which tends to be conducted for early childhood and primary school students. There is Al-Qur'an learning method for adults, namely the method of Dirosa (Dirasah Orang Dewasa), but this method requires a relatively long time, which is approximately 20 meetings.

The efforts that had been made to eradicate Al-Qur'an illiteracy in students had reached the preparation of Al-Qur'an literacy design or learning models. This learning model is called as TAHQIQ proposed by Supriyadi \& Julia (2019) as the results of their previous research. TAHQIQ is a conceptual framework used as a guideline in carrying out an Al-Qur'an illiteracy eradication activity. Joyce, Weils and Calhoun (1996) stated that learning model can be meant as a plan or pattern that is used as a guideline in planning classroom learning or tutorial learning by determining learning tools, including books, films, computers, etc., which can help students achieve learning goals.

This TAHQIQ model aims at improving the students' ability in reading Al-Qur'an. In addition, THAQIQ is also compiled with styles of learning and teaching that are in 
Tedi Supriyadi, J. Julia, Prana Dwija Iswara \& Ani Nur Aeni, Eradicating Al-Qur'an Illiteracy...

accordance with the subjects, e.g., students. Since the learning model is related to styles of learning and teaching (Hanafiah \& Suhana, 2009), this research aims at analyzing the implementation of the TAHQIQ learning model in eradicating Al-Qur'an illiteracy in the students.

\section{METHOD}

\section{Research Design}

This research employed the action research design, which is based on many research methods of action research in literature as a design in solving problems in the field of education (Adelman, 1993; Capobianco \& Feldman, 2006; Jefferson, 2014; Niemi, 2018). Moreover, an action research provides an opportunity for researchers to discover new change efforts that are in accordance with its conditions and needs (Darwis, 2016). Through this action research, the researchers seek to find solutions to practical problems (Creswell, 2002). In this research, the researchers examined the problems related to the students' ability in reading Al-Qur'an, and then conducted a series of actions as problem-solving solutions. This series was provided to find solutions, which referred to the steps in the TAHQIQ learning model.

In conducting the research, the researchers used the principles of collaboration as characteristics of the design action research (Creswell, 2002). This collaboration involved the researchers (as supporting lecturers of the PAl course), the colleagues (as supporting lecturers of the PAl course in each study program), a lecturer who has expertise in the field of music, since in the practice of phonology of Al-Qur'an used musical melodies, and a lecturer who has expertise in the field of linguistics. Furthermore, the researchers also collaborated with one of the student activity units that studies Al-Qur'an who were invited to be involved in a series of actions conducted. Studies that employ collaborative action research processes in education involve collaboration between teachers, or between teachers and researchers (Messiou, 2018; Zech, GauseVega, Bray, Secules, \& Goldman, 2000).

\section{Research Site and Subject}

This research was conducted in one of the universities in the PGSD (Pendidikan Guru Sekolah Dasar - Primary School Teacher Education) study program, in Sumedang Regency. The research subjects were 360 prospective primary school teachers, consisting of 130 male and 240 female teachers. They were in the same class who took the PAl course. Moreover, they are from various regencies in two provinces, namely West Java and Central Java. From Central Java, it consisted of 21 students were from Cirebon Regency, 34 students were from Indramayu Regency, and 15 students were from Brebes Regency. Meanwhile from West Java, it consisted of 120 students who were from Bandung Regency and 180 students who were from Sumedang Regency. 


\section{Data Collection and Analysis}

In this research, the data were collected in several techniques, including: 1) observation, which was conducted to observe the learning process of reading AlQur'an through actions referring to the TAHQIQ model; 2) interview, which was conducted to explore opinions about their conditions related to their skills in reading Al-Qur'an and their perspective after following a series of actions; and 3) test of Al-Qur'an reading skills, which was conducted at pre-test and post-test to find out the initial conditions and the final results of the actions.

\section{RESULT}

Overall, this research was divided into three sections. First, pre-action analysis, which was used to examine the problems and ability of the students' Al-Qur'an reading ability. Second, the implementation of TAHQIQ model, to provide a number of actions or treatments to the research subjects. Third, post-action evaluation, to analyze the results of implementation of the TAHQIQ model.

\section{Pre-action Analysis}

The initial stage of implementation of the TAHQIQ model was to examine and review the students' initial Qur'an reading ability by conducting the test on the students. In measuring the students' ability in reading Al-Qur'an, this research referred to Supriyadi \& Julia's (2019) indicators, as presented in Table 1 below.

Table 1. The Indicators of Al-Qur'an Reading Ability (Supriyadi \& Julia, 2019).

\begin{tabular}{|c|c|c|}
\hline $\begin{array}{l}\text { Level of } \\
\text { Ability }\end{array}$ & Main Characteristics & Category \\
\hline \multirow{3}{*}{ Ibtida 1} & 1. Does not recognize hijaiyyah letters with diacritics & \multirow{3}{*}{$\begin{array}{l}\text { Very Not } \\
\text { Fluent }\end{array}$} \\
\hline & 2. Can read hijaiyyah letters, but it is still often confused & \\
\hline & $\begin{array}{l}\text { 3. Can read hijaiyyah letters, but cannot read distinct forms of } \\
\text { hijaiyyah letters }\end{array}$ & \\
\hline \multirow{3}{*}{ Ibtida 2} & 1. Can read distinct forms of hijaiyyah letters in 3 or 4 letters & \multirow{3}{*}{ Not Fluent } \\
\hline & $\begin{array}{l}\text { 2. Can read distinct forms of hijaiyyah letters, but makhroj is still } \\
\text { incorrect and confused in its use }\end{array}$ & \\
\hline & 3. Read it slowly and haltingly & \\
\hline \multirow{3}{*}{ Ibtida 3} & 1. Read distinct forms of hijaiyyah letters fluently and correctly & \multirow{3}{*}{ Less Fluent } \\
\hline & 2. Read it smoothly and clearly & \\
\hline & 3. Implement tajweed incorrectly & \\
\hline
\end{tabular}


Tedi Supriyadi, J. Julia, Prana Dwija Iswara \& Ani Nur Aeni, Eradicating Al-Qur'an Illiteracy...

\begin{tabular}{lll}
\hline & 1. Read Al-Qur'an fluently and correctly & \\
Jayyid & 2. Pronunciation (makhroj) is correct & Fluent \\
& 3. Implement tajweed correctly & \\
4. Understand a little about the theory of tajweed & 1. Read Al-Qur'an fluently and correctly & \\
Jayyid & 2. Pronunciation (makhroj) is correct & Very Fluent \\
3idan & 3. Implement tajweed correctly & \\
& 4. Understand the theory of tajweed & \\
\hline
\end{tabular}

There were 10 active students in students' organizations during the development unit of tilawatil Al-Qur'an with a level of Jayyid ability in reading Al-Qur'an who were invited to be involved as the collaborators in conducting a pre-test. These ten students were given several training to become candidates for tutors in attempting to understand the steps of the TAHQIQ learning, and improve the prospective tutors' AI-Qur'an reading ability to the level of Jayyid Jiddan.
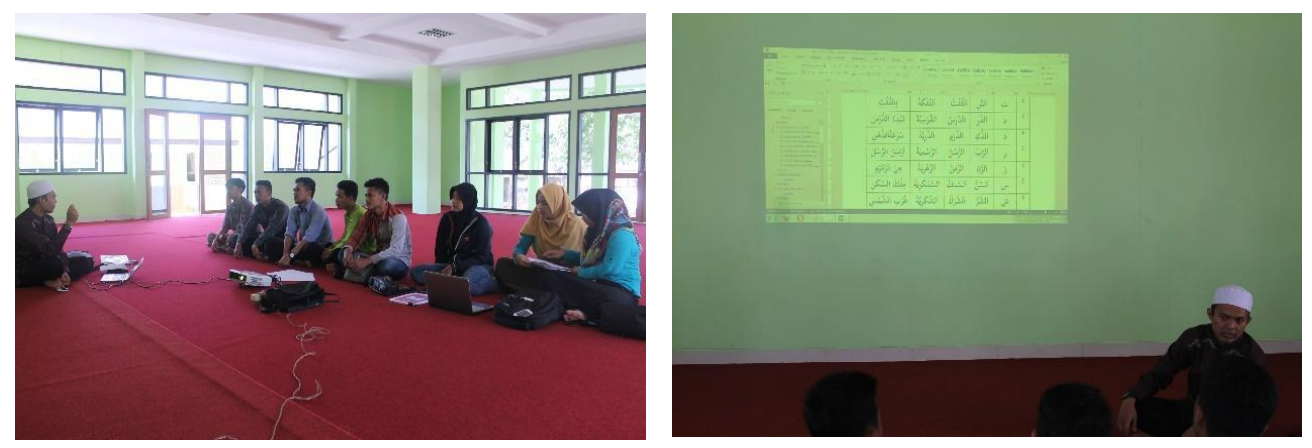

Figure 1. Practicing Process for Tutors.

Based on the result of the training, there were several weaknesses in implementing the indicators of Al-Qur'an reading ability in which there were still different perceptions among tutors when testing the same student. Hence, the researchers made a number of revisions to the main indicators listed in Table 1. The following Table 2 presents the revised indicators.

Table 2. The Indicators of Al-Qur'an Reading Ability.

\begin{tabular}{lll}
\hline $\begin{array}{l}\text { Level of } \\
\text { Ability }\end{array}$ & Main Characteristics & Category \\
\hline & 1. Do not recognize hijaiyyah letters with diacritics & \\
Ibtida 1 & 2. Can mention hijaiyyah letters with diacritics, but it is & Very Non-Fluent \\
& 3till often confused & Can mentioned hijaiyyah letters with diacritic forms, \\
\hline
\end{tabular}




\begin{tabular}{|c|c|c|c|}
\hline & & for example, fathah, kasrah and ḍammah & \\
\hline & 4. & $\begin{array}{l}\text { Can mentioned hijaiyyah letters with a diacritic form, } \\
\text { namely tanwin }\end{array}$ & \\
\hline & 5. & Pronounce hijaiyyah letters incorrectly & \\
\hline \multirow{3}{*}{ Ibtida 2} & & $\begin{array}{l}\text { Can read distinct forms of hijaiyyah letters in } 3 \text { or } 4 \\
\text { letters, but it is still often confused with diacritics. }\end{array}$ & \multirow{3}{*}{ Non-Fluent } \\
\hline & 2. & $\begin{array}{l}\text { Can read distinct forms of hijaiyyah letters in } 3 \text { or } 4 \\
\text { letters with correct diacritics, but the pronunciation } \\
\text { (makhroj) is still incorrect }\end{array}$ & \\
\hline & \multicolumn{2}{|r|}{ 3. Point 1 and 2 have been correct, but read it haltingly } & \\
\hline \multirow{4}{*}{ Ibtida 3} & & $\begin{array}{l}\text { Can read distinct forms of hijaiyyah letters fluently } \\
\text { and correctly }\end{array}$ & \multirow{4}{*}{ Less Fluent } \\
\hline & & Not confused with diacritics & \\
\hline & & $\begin{array}{l}\text { Can pronounce hijaiyyah letters with diacritic forms, } \\
\text { for example, tashdid and sukūn }\end{array}$ & \\
\hline & 4. & Implement tajweed incorrectly & \\
\hline
\end{tabular}

1. Can read Al-Qur'an fluently and correctly

Jayyid

2. Pronunciation (makhroj) is correct

3. Implement tajweed correctly

Fluent

4. Understand a little about the theory of tajweed

1. Read Al-Qur'an fluently and correctly

Jayyid Jidan

2. Read Al-Qur'an rhythmically

Very Fluent

3. Can mention the theory of tajweed

Referring to the indicators presented in Table 2, the result of pre-test given to 370 students indicated that students' ability in reading Al-Qur'an was still low, as presented in Table 3.

Table 3. The Result of Pre-test of the Students' Ability in Reading Al-Qur'an.

\begin{tabular}{lll}
\hline Level & Total & Percentage \\
\hline Ibtida 1 & 34 & 9.19 \\
Ibtida 2 & 103 & 27.84 \\
Ibtida 3 & 157 & 42.43 \\
Jayyid & 76 & 20.54
\end{tabular}

$\begin{array}{lll}\text { Jayyid } & 0 & 0.00 \\ \text { Jiddan }\end{array}$

Table 3 presents that there were 34 (9.19\%) students in the very non-fluent category, $103(27.84 \%)$ students in the non-fluent category, 157 (42.43\%) students in the lessfluent category, and $76(20.54 \%)$ students in the fluent category. Therefore, it indicated that there were only 76 (20.54\%) students who had Al-Qur'an reading ability, while 294 (80.46\%) students still did not have ability in reading Al-Qur'an.

Lack of students' ability in reading AlQur'an could affect students' 
Tedi Supriyadi, J. Julia, Prana Dwija Iswara \& Ani Nur Aeni, Eradicating Al-Qur'an Illiteracy...

achievement in the PAl course, because the contents of the PAI material discuss the sources of Islamic teachings, one of which is Al-Qur'an. Several researches have proven the relationship between Al-Qur'an reading ability and the learning achievement, Adam (2008) and Husna (2015) found that there was a significant relationship between Al-Qur'an reading ability and learning achievement in Islamic Religious Education. In other words, the individuals' ability in reading Al-Qur'an affects the learning achievement in the PAl course.

On the other hand, Al-Qur'an reading ability does not only affect learning achievement, but also the level of students' emotions. By having Al-Qur'an reading ability, it can encourage the individual to get used to reading and listening Al-Qur'an, because of the habit of reading and listening to it, it will affect emotional stability (Fadhillah, 2016), even decrease the level of individuals' depression and anxiety (Abdullah \& Malkawi, 1994; Babamohamadi et al., 2017; Ghiasi \& Keramat, 2018).

Based on these findings, the researchers as the PAI supporting lecturers collaborated with other PAl lecturers to build a commitment together in establishing requirements to pass the PAl course by having the Al-Qur'an reading ability in the minimum level of Jayyid. In other words, if the students have not been passed the level of Jayyid, their completions in the PAI course are deferred. This effort is carried out to stimulate students' motivation to improve their Al-Qur'an reading ability, and it is also considered as efforts in developing and reviving the development unit of tilawatil Qur'an as an assistance forum for the PAl course in fostering students who have not had the Al-Qur'an reading ability while taking the $\mathrm{PAl}$ course. This issue is not merely the responsibility of PAl lecturers, but it is everyone's responsibility who actively participates in the academic unity.

\section{Analysis of Implementation of the TAHQIQ Model}

This stage is a series of actions given to the research subjects as attempts to improve the students' Al-Qur'an reading ability. The following are the steps taken in the series of actions.

\section{Grouping Mapping Step}

Referring to the pre-test results, the students were categorized based on the level of reading ability. The results were categorized into 32 groups. Each level was divided into 10 groups. Moreover, the level of Jayyid was divided into 2 groups. Each level, especially from the levels of Ibtida 1 to Ibtida 3, would obtain different material with the same target, reached minimum level of Jayyid. Likewise for the level of Jayyid, they would obtain material focused on deepening the theory of tajweed and understanding the TAHQIQ learning model as the effort to regenerate peer tutors. In addition, it could be used to help students who were at the level of 
Ibtida 1 to Ibtida 3 in the process of reading Al-Qur'an.

The ten futors who had been trained were mapped to provide material at each level. The ratio between students and tutors was, in Ibtida 1 with a total of 34 students, each tutor accompanied 3-4 students. This was because the students at Ibtida 1 required intensive guidance and hard work to increase the ability to the level of Jayyid. For Ibtida 2, each tutor accompanied 1011 students with the aims of increasing the ability to the level of Jayyid. For Ibtida 3, each tutor accompanied 15-16 students with the aims of increasing the ability to the level of Jayyid. Furthermore, the student at the level of Jayyid were directly tutored by the researchers as the PAl lecturers collaborated with other lecturers who taught the same subjects in attempting to improve their reading ability from the levels of Jayyid to Jayyid Jiddan.

To get to the next level, which required 3-4 meetings, a guidance activity was done once a week and the habituation activity by tutor was scheduled four times in a week. This practice was accompanied with a classmate (who was at the level of Jayyid), in four meetings. Hence, there were 12 meetings required by the students at Ibtida 1, 8 meetings required by the students at Ibtida 2, and 4 meetings required by the students at Ibtida 3 .

The lecturer directly tutored the students at the level of Jayyid by conducting 12 meetings per week in aims of increasing their ability to the level of Jayyid Jiddan. The number of these meetings was designed due to the complexity and depth of tajweed materials that must be mastered. Moreover, this was also considered as the monitoring form of the lecturers on the students at the levels of Ibtida 1 to Ibtida 3 to form Al-Qur'an reading habituation. The students who were at the level of Jayyid would accompany them as peer tutors. Therefore, this step is described in the following Table 4.

Table 4. Ratio of Tutors, Target and Total Meetings.

\begin{tabular}{lllll}
\hline \multirow{2}{*}{ Level } & $\begin{array}{l}\text { Total } \\
\text { Participants }\end{array}$ & $\begin{array}{l}\text { Ratio of Participants and } \\
\text { Tutors }\end{array}$ & Target & Total Meetings \\
\hline Ibtida 1 & 34 & $1: 3$ & 3 Level & 12 \\
Ibtida 2 & 103 & $1: 10$ & 2 Level & 8 \\
Ibtida 3 & 157 & $1: 15$ & 1 Level & 4 \\
Jayyid & 76 & $1: 38$ & 1 Level & 12 \\
\hline
\end{tabular}

\section{Al-Qur'an Learning Step}

This step is the Al-Qur'an learning process. At each level, the students were given materials by referring to two TAHQIQ books. Book 1 was intended for the students at the levels of Ibtida 1 and Ibtida 2. while Book 2 was intended for the students at the level of Ibtida 3 . For the students at the level of Jayyid, their teaching resource used the Androidbased application of Learn Qur'an Tajwid 
Tedi Supriyadi, J. Julia, Prana Dwija Iswara \& Ani Nur Aeni, Eradicating Al-Qur'an Illiteracy...

(LQT) created by www.learn-quran.co.id that is available to be downloaded in Google Play Store.

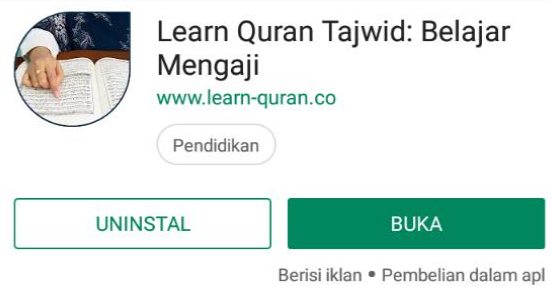

Figure 2. Display of the Application in Google Play Store.

Book 1 covers two sections. The first section includes the introduction of hijaiyyah letters and diacritics intended for Ibtida 1, while the second section includes the distinct forms of hijaiyyah letters and how to read alif lam qomariyah and syamsiah intended for Ibtida 2. Book 2 includes material about the introduction and identification of short length readings in AlQur'an, and also applicable tajweed. The following Figure 3 depicts the LQT application that discusses tajweed.

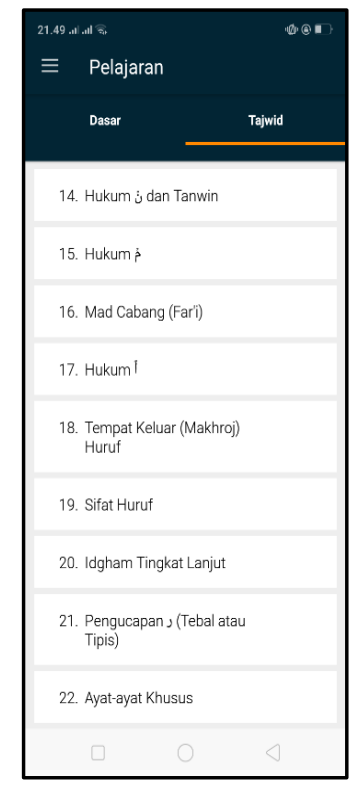

Figure 3. Display of the Features of Learn Qur'an Tajwid in Google Play Store.
The learning process for Ibtida 1 emphasized on the link between the letters forms and other objects, for example, the $J$ is associated with a fish hook, the $r$ is associated with a fist, and the $\dot{v}$ is associated with a bowl, etc., this process aims at facilitating memorizing letters. In terms of the sound of letters, the link is associated by another sound, e.g., the sound of the $z$ is associated with the sound of people who taste spiciness. This process aims at facilitating the memorizing of letters sound. The learning process for Ibtida 2 emphasized on the writing (imla), for example, a tutor expresses the word "BAJU", and then the students write in hijaiyyah letters with diacritics, followed by pronouncing and writing it with distinct forms. In Ibtida 3, the material was given classically related to the characteristics of long and short reading, and the way to pronounce, such as iẓhār, idghām, Ikhfā', lalāb and ghunnah. This process emphasized on the practical application of tajweed, but it did not explain the theory and terms of tajweed. The learning process for Jayyid emphasized on the learning tajweed, the implementation of the theory in reading Al-Qur'an, and the habit in reading with murotal rhythm. This learning process related to the length of time was in accordance with the time plan that had been arranged, e.g. the level of Ibtida 1 to Ibtida 2 required 4 meetings, and likewise from the level of Ibtida 2 to Ibtida 3 , and from the level of Ibtida 3 to Jayyid. 
From this learning process, the findings revealed several issues: the absence of students or tutors in the activities due to a sudden change of course schedule, thus affecting in schedule conflict. This conflict could be anticipated by changing the tutor time agreed mutually by the tutors and the students. However, in overall, this learning process was able to increase the students' learning motivation, thus it could improve the students' Al-Qur'an reading ability.

\section{Accustomed Step}

This accustomed step was a follow-up of the previous steps, and a strategy in making the students accustomed to continue learning, hence, the obtained material was truly mastered. Accustomed material was conducted every day outside the lecture time, the students were accustomed to being accompanied by their classmates who were in the level of Jayyid (hereinafter referred to as a class tutor). Based on the mapping results, there were 76 students at the level of Jayyid and 294 students at the levels of Ibtida 1-3 with the ratio of 1:3. Each class tutor was responsible to accompany three friends with a variety of levels. This was conducted to regenerate tutor and monitor the habit of students.

The students at the level of Ibtida 1 were accustomed to recognizing the letters and the diacritics. They were accompanied by a class tutor to master the practical materials in the available book in accordance with the material that had been given when participating in the practices. The students were asked to practice pronunciation in order to familiarize to pronounce (makhroj) using the following syllables:

Example 1. The hijaiyyah letter of Alif

$$
\text { 醇 }
$$

Example 2. The hijaiyyah letter of $\mathrm{Ba}$

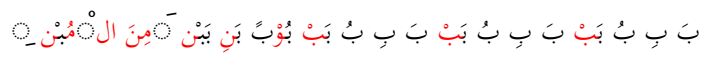

$$
\begin{aligned}
& \text { مَبِيْبَ بَبَبَّا }
\end{aligned}
$$

Example 3. The hijaiyyah letter Ta

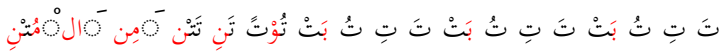

$$
\begin{aligned}
& \text { مَتَتْنًَا تنتِنَا }
\end{aligned}
$$

The above reading follows the melody presented in Figure 4.

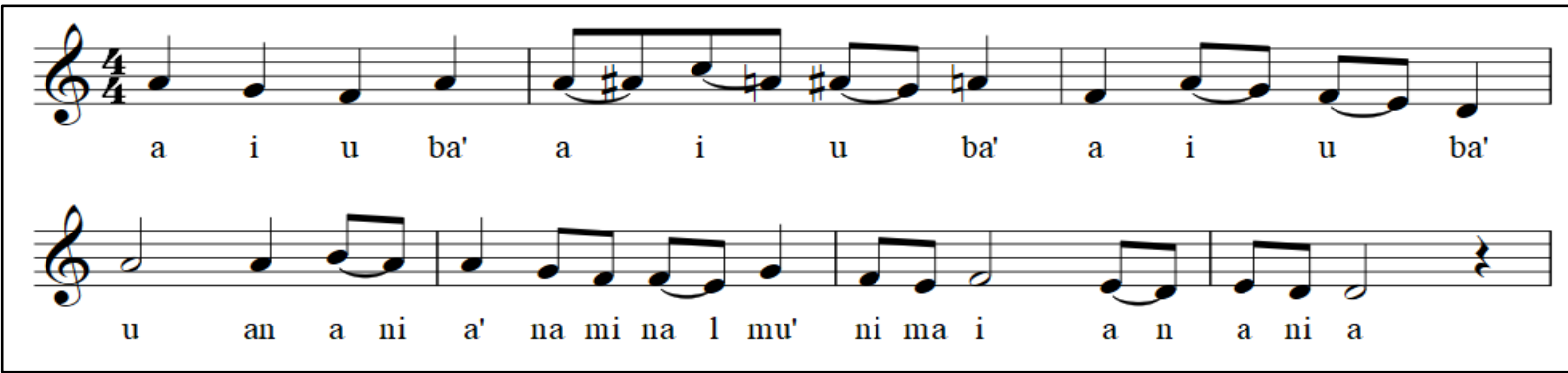

Figure 4. Learning Method in Pronouncing (Makhroj) (Supriyadi \& Julia, 2019). 
This technique was not only accustomed to being given to students at the level of Ibtida 1, but also given to Ibtida 2 and Ibtida 3 in an effort to improve the accuracy of the pronunciation (makhroj). In addition, there was a special habit for Ibtida 2 and 3, which was to work and read out the practices that are available in the book for each sub-material. For example, those at Ibtida 2 were getting used to write the word with hijaiyyah letters and their diacritics. The students at Ibtida 3 were getting used to read the readings in the available books, which were read aloud by a class tutor. A class tutor was accustomed to listening to short surahs read by the famous Qari, for instances Syeikh Suda'is, in the form of murotal. Furthermore, they followed and recorded it on the LQT application.

This method was considered to be quite effective in attempting to master the material that had been taught at each level, because there were a number of improvements in differentiating the letters with the similar forms, but the pronunciation was different so that it could minimize the confusing letters sounds. For class tutors, they were expected to have a rhythm in reading Al-Qur'an.

\section{Material Reinforcement and Repetition Step}

After conducting an accustomed step accompanied by class tutors, the tutors' efforts in the learning process was to conduct reinforcement by repeating materials presented in the previous meetings. This was carried out to ensure that the previous material was completely mastered, which was done by examining each sub-test on available teaching resources.

Based on the results of this step, the findings revealed that the Al-Qur'an reading ability for the students at the level of Ibtida 1 to Ibtida 3 had improved, and the majority of the students could master the material presented in the previous meetings. The indicators of improvement at the level of Ibtida 1 showed that 30 out of 34 students at Ibtida 1 had been no longer confused in mentioning letters and sounding letters with didactic forms. While at the level of Ibtida 2, the majority of the students had been able to read distinct forms of hijaiyyah letters in 3-4 letters correctly. Furthermore, at the level of Ibtida 3, the students had been able to read 1-2 short surahs fluently and correctly. In addition, the students at the level of Jayyid had been able to read Al- Qur'an rhythmically, as in the form of murotal. Repetition of material took 15-20 minutes.

\section{Evaluation Step}

Evaluation was conducted by the tutors to measure the achievement, and ensure the existence of improvement in students' AlQur'an reading ability. The evaluation was divided into two objectives. First, to ensure the mastery of each sub-material given at each meeting according to the indicators 
at each level. Second, to ensure the level improvement in every four meetings.

Each evaluation conducted by the futors produced the report given to the lecturers, in this case the researchers, and the collaborator team, including the lecturers who taught the PAl course. Based on the result of the tutors' evaluation, the findings revealed that there were still students who tended to be slow in ideally improving their abilities in every four meetings, for instance, from the level of Ibtida 1 to Ibtida 2, or from the level of Ibtida 2 to Ibtida 3 , etc. In fact, there were the students who had not changed at all. From these findings, the researchers conducted interview to the tutors who guided the students. The findings revealed that the students tended to be slow in improving their ability in every four meetings, because they rarely participated in the accustomed activity accompanied by a class tutor. Based on the predetermined schedule for an accustomed activity, on the average, the students only participated in the activity for 1-2 meetings. During the interview section, the researchers asked several questions related to their reasons to be not participated in the accustomed activity. The students reasoned that they were busy accomplishing other courses' tasks, and participating in the event organized by the organization. Even though their answers implied the rejection toward this activity, some students still expressed their willingness to participate in this activity to quickly improve their Al-Qur'an reading ability. Therefore, the findings indicated that the students actually had the desire to participate in an accustomed activity, but they had also issues regarding their responsibilities and priorities as students.

On the other hand, there were the students who experienced stagnation, thus they could not improve their ability. It was caused by infrequent attendance in training programs organized by the tutors, so that they did not obtain the main material. After conducting the interview by asking about their absence in participating in training program, they reasoned that they had a conflict schedule with the assignment of other courses, family gathering, schedule forgotten, exhausted factors due to carry out the assignment until late night, etc. Furthermore, when the researchers asked the question regarding their willingness to be able reading AlQur'an, all students, especially at the level of Ibtida 1 to 3, who did not have an improvement answered that they were motivated to be able to read it. This indicated that there were the issues regarding their responsibilities and priorities as students. In addition, they also understood that the Al-Qur'an reading ability must definitely be possessed by a Muslim.

\section{Post-action Evaluation}

The students who had passed the learning steps to eradicate Al-Qur'an illiteracy, both diligent students and students with a 
Tedi Supriyadi, J. Julia, Prana Dwija Iswara \& Ani Nur Aeni, Eradicating Al-Qur'an Illiteracy...

minimal presence in participating in the activity process, carried out the post-test to ascertain whether they had the minimum ability in reading $\mathrm{Al}-\mathrm{Qur}$ an or not, the extent of the development of the students' improvement in reading AlQur'an. The post-test was conducted by the researchers, involving the collaborator team that consisted of the PAl lecturers. The following Table 5 presents the post-test result.

Table 5. The Post-test Result of Reading AlQur'an.

\begin{tabular}{lll}
\hline Level & Total & Percentage \\
\hline Ibtida 1 & 5 & 1.35 \\
Ibtida 2 & 10 & 2.70 \\
Ibtida 3 & 15 & 4.05 \\
Jayyid & 223 & 60.27 \\
Jayyid & 117 & 31.62 \\
\hline Jiddan & &
\end{tabular}

$N=370$
Table 5 shows that overall students experienced improvement in Al-Qur'an reading ability, because majority of the students had reached the minimum requirement of $\mathrm{Al}$-Qur'an reading ability. This can be seen from the combination of the number of students at the levels of Jayyid and Jayyid Jiddan that was 340 (91.89\%) students, consisting of 223 (60.27\%) students at the level of Jayyid and $117(31.62 \%)$ students at the level of Jayyid Jiddan. Meanwhile, the number of students who were not fluent, or had not reached the minimum ability was 30 (8.1\%) students, consisting of 5 (1.35\%) students at the level of Ibtida 1, 10 (2.70\%) students at the level of Ibtida 2, and 15 (4.051\%) students at the level of Ibtida 3.

The following Figure 5 depicts the shift at the level of Al-Qur'an reading ability based on pre-test and post-test results.

The Improvement of Al-Qur'an Reading Ability

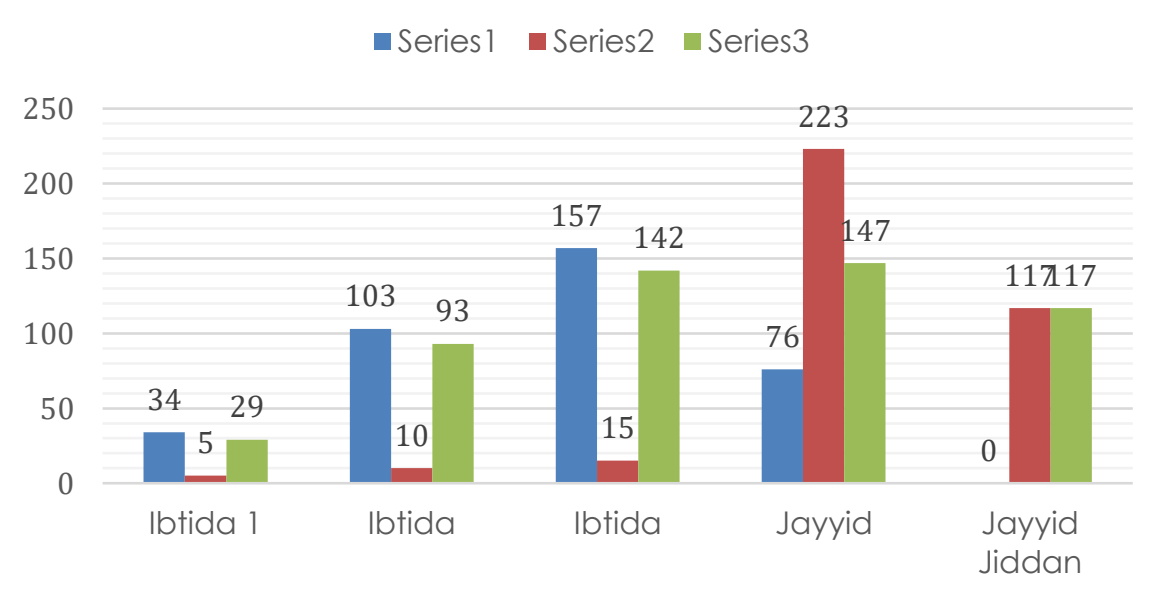

Figure 5. The Improvement of Al-Qur'an Reading Ability.

Figure 5 depicts that there was a shift at the level of students' Al-Qur'an reading ability by employing the TAHQIQ Al-Quran learning model. Based on the results of 
pre-test and post-test, the numbers of students at the level of Ibtida I had decreased by 29 students with the remaining 5 students, thus it indicated that 29 students had improved their Al-Qur'an reading ability. Meanwhile, the numbers of students at the level of Ibtida 2 had decreased by 93 students with the remaining 10 students, thus it indicated that 93 student had improved their AlQur'an reading ability. Next, the numbers of students at the level of Ibtida 3 had decreased by 142 students with the remaining 15 students, which indicated that 142 students had improved their AlQur'an reading ability. In addition, the numbers of students at the level of Jayyid was able to increase by 145 students. Even though there were not students at the level of Jayyid Jiddan in pre-test, after the conducting the post-test, it was found that there were 117 students improved to this level.

The forms of improvement in the students' Al-Qur'an reading ability were diverse. There were students who improved at one step gradually, and there were also students who improved rapidly from pretest to post-test. For example, the students who were at the level of Ibtida 1 in pre-test were able to improve their ability into the levels of Ibtida 2, Ibtida 3, and even Jayyid after conducting post-test, likewise for the students who were at the level of Ibtida 2 in pre-test. The followings are the forms of improvement in Al-Qur'an reading ability presented in Table 6.

Table 6. The Forms of Improvement in Al-Qur'an Reading Ability.

\begin{tabular}{llllll}
\hline From/To & Ibtida $\mathbf{1}$ & Ibtida 2 & Ibtida & Ibtida & Jayyid Jiddan \\
\hline Ibtida 1 & 5 & 4 & 5 & 20 & \\
Ibtida 2 & 6 & 7 & 79 & 11 \\
Ibtida 3 & & 3 & 115 & 39 \\
Jayyid & & & & 9 & 67 \\
\hline
\end{tabular}

Table 6 shows that there were a varied number of improvements based on pretest and post-test results, namely based on 34 students at the level of Ibtida 1 in pretest, after conducting the post-test, 5 students had not improved, 4 students improved one level from the level of Ibtida 1 to Ibtida 2, 5 students improved two levels from Ibtida 1 to Ibtida 3, and 20 students shifted three levels from Ibtida 1 to Jayyid. Therefore, the total of students who experienced the improvement was 29 students.

Based on 103 students at the level of Ibtida 2 in pre-test, after conducting the posttest, 6 students had not improved, 7 students improved one level from Ibtida 2 to Ibtida 3, 79 students improved from Ibtida 2 to Jayyid, and 11 students improved to Jayyid Jiddan. 
Tedi Supriyadi, J. Julia, Prana Dwija Iswara \& Ani Nur Aeni, Eradicating Al-Qur'an Illiteracy...

Based on 157 students at the level of Ibtida 3 in pre-test, after conducting the posttest, 3 students had not improved, 115 students improved one level from Ibtida 3 to Jayyid, and 39 students improved to Jayyid Jiddan. Finally, based on 76 students at the level of Jayyid in pre-test, after conducting the post-test, 9 students had not improved, and 67 students improved to the level of Jayyid Jiddan.

The data above proved that the TAHQIQ learning model was able to improve the students' ability in reading Al-Qu'ran. It can be seen from the comparison between the pre-test and post-test results. When conducting pre-test, the number of students with minimal ability in reading AlQur'an, namely at the level of Jayyid, was 76 (20.54\%) students. Meanwhile, after conducting post-test, the number of students with minimal ability in reading AlQu'ran was 340 (91.8\%) students who were combination between 223 (60.27\%) students at the level of Jayyid and 117 $(31.62 \%)$ students at the level of Jayyid Jiddan. These results indicated that the TAHQIQ learning model was able to eradicate Al-Qur'an illiteracy, and improve the students' Al-Qur'an reading ability, reaching 264 (70\%) students.

\section{DISCUSSION}

The results of this action research provided a new understanding that someone can improve their Al-Qur'an reading ability well and correctly without having to take a long time until many years. This research proved that the students improved significantly after participating in 12 meetings. By providing the learning of AlQuran reading ability, everyone will be able to get used to read, understand, and implement Al-Qur'an in their daily Life. Since Al-Qur'an is the Islamic teaching guidelines that must be learned (Shihab, 1992), hence, Al-Qur'an reading ability is the initial stage that must be passed by every Muslim in order to understand the teaching resources. This is the implicit meaning of the Prophet's message to every Muslim in order to always learn and teach Al-Qur'an (Bukhori, 1992 No 5027).

In addition, this research results attempted to provide a new understanding of the purposes of learning Al-Qur'an at the first level, namely in terms of reading Al-Qur'an to students. The main objective is that every student can read A-Qur'an well and correctly, this is as commanded by Allah in Al-Qur'an 73:4:

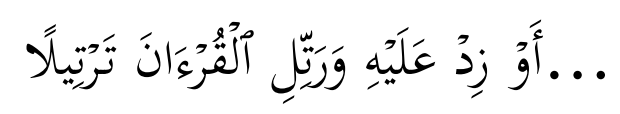

"Or add to it, and recite the Qur'an with measured recitation (tartil)" (Ministry of Religious Affairs, 2005).

The concept of tartiil is the method of reading slowly by stopping and starting to read in order to clarify letters, thus the readers and listeners can understand and appreciate the content of the messages (Katsir, 2000). Furthermore, the necessity of reading Al-Qur'an beautifully is conveyed by the Prophet Muhammad (PBUH) narrated by Imam Ahmad bin Hanbal 
(2001) in Hadith Number 18994 and AlNasa'i (1991) in Hadith Number 1016:

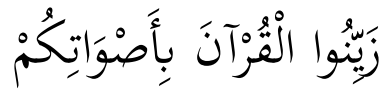

"Make your voices beautiful when you recite Quran."

The effort to decorate Al-Qu'ran with good voices is by reading rhythmically, Imam Bukhari (1992) in Hadith Number 7527, narrated by Abu Hurairah:

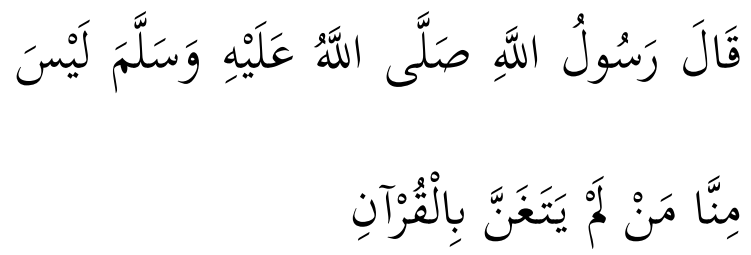

"Whoever does not recite Qur'an in a nice voice is not from us."

Moreover, from normative aspects, this research also showed that there was a serious issue in the PAl learning process at the previous level of education. As it is known that in Indonesia, the PAl subject is given from the primary school level for 6 years, junior high school for 3 years and high school for 3 years. During the 12 years of the PAl subjects, the problem of students in reading Al-Qur'an has not been able to be resolved, even though it can be solved with just a few meetings. This problem is probably very closely related to the professionalism of the teacher in teaching. Teachers might want to be practical without having any difficulty. Even though teacher professional learning is a complex process, which requires cognitive and emotional involvement of teachers individually and collectively, the capacity and willingness to examine where each one stands in terms of convictions and beliefs and the perusal and enactment of appropriate alternatives for improvement or change (Avalos, 2011).

Related to this issue, the teachers need to continuously reflect themselves and attempt improving the learning quality. By understanding styles of learning and teaching, it can create a change in the learning process. This indicated that the teachers have to realize entirely that the learning steps taken in the learning process are not able to provide the satisfactory results, thus, it requires the development or preparation of innovative and futuristic models. In addition to the learning model closely related to styles of learning and teaching, learning models can also be considered as an approach to cope with changes in adaptive and generative behavior of students (Hanafiah \& Suhana, 2009). In addition, the learning model can also help the students achieve the purpose of the learning (Joyce, B. Weils, M. Calhoun, 1996).

The teachers' ability to develop models suggests that the teachers must also have literacy skills, by exploring studies that can improve their abilities, for example how teacher learning is a professional learning method, for example, how teacher learning is researched to propose or 
Tedi Supriyadi, J. Julia, Prana Dwija Iswara \& Ani Nur Aeni, Eradicating Al-Qur'an Illiteracy...

discuss models of teacher professional learning (Castle, 2006; James \& McCormick, 2009; Nisbet \& Shucksmith, 2017; Novak \& Gowin, 1984; Olson \& Craig, 2001). This is carried out in order to recognize how teachers learn and change by developing theory or applying theory to the discussion of teacher change (Clarke \& Hollingsworth, 2002; Korthagen, 2010; Korthagen, 2007; Penlington, 2008). Therefore, this research results require the teachers to practice the action research approach to improve and increase the learning quality.

\section{CONCLUSION}

This research has proved that the TAHQIQ learning model was able to eradicate AlQur'an illiteracy and improve Al-Qur'an reading ability at the college level in 12 meetings and by adding a number of accustomed activities as a form of practice. The TAHQIQ steps included (1) the mapping and grouping processes as a step to examine and review the issues in reading Al-Qur'an; (2) the learning process as an effort to guide the changes and the improvement of ability; (3) the accustomed process as a form of action steps to memorize and refine the way to read by ensuring mastery of every material; and (4) the process of reinforcement and repetition of material as a real implementation in the Qira'at, which is the practice of reciting Al-Qur'an through sub-material testing while reminding the errors in reading carried out by tutors in order to achieve the purpose of learning to actualize a Qori (Reader) of Al-Qur'an. TAHQIQ is an acronym of these steps: Ielaah, Arahkan, ㅂapalkan dan Haluskan, Qira'atkan, Ingatkan and Q as the purpose of learning lobserve, Guide, $\underline{M}$ emorize and $\underline{R}$ efine, $\underline{R} e c i t e$, Remind and Qori).

These steps as the action given in the TAHQIQ model had been able to provide significant changes in the effort to eradicate Al-Qu'ran at the college level. This high rate of decline also has an effect on the decline in the rate of Al-Qur'an illiteracy in Indonesia, which is still considered relatively high. Therefore, the TAHQIQ learning model can be a solution for anyone who desires to have the ability to read Al-Qur'an quickly and correctly, because it only takes 12 meetings, the learning is directed at the problems perceived by the learners. However, this TAHQIQ learning model still had a great opportunity to be developed continuously.

\section{REFERENCES}

Abdou, S. M., \& Rashwan, M. (2014). A Computer Aided Pronunciation Learning system for teaching the holy quran Recitation rules. In 2014 IEEE/ACS 11th International Conference on Computer Systems and Applications (AICCSA) (pp. 543550).

Abdullah, A.-R. S., \& Malkawi, F. H. (1994). The Effect of the Time Factor on Learning the Recitation of the Holy Qur'an: An Experimental Study. Journal of Islamic Studies, 6(2), 33313. Retrieved from https://doaj.org/article/c3c52470aa4 b460e90cd8c85e3d6c9f8

Adam, Z.A. (2008). Pengaruh Tingkat Penguasaan Baca Tulis Al-Qur'an 
terhadap Prestasi Pendidikan Agama Islam Siswa di SMA Negeri 1 Pangkajene Kabupaten Pangkep. UIN Alauddin Makassar.

Adelman, C. (1993). Kurt Lewin and the Origins of Action Research. Educational Action Research, 1 (1), 724.

https://doi.org/10.1080/096507993001 0102

Al-Nasa'i, A. al. (1991). Sunan al-Nasa'i. Cet. II. Halab. Maktab Al-Matbu 'at Al-Islamiyah, 1406.

Arifin, T. (2017, 14 December). 54 \% Muslim Indonesia Buta Huruf Al-Qur'an. Pikiran Rakyat. Retrieved from https://www.pikiran-

rakyat.com/nasional/2017/12/14/ironi s-54-muslim-indonesia-tak-bisa-bacaalquran-415880

Avalos, B. (2011). Teacher professional development in teaching and teacher education over ten years. Teaching and Teacher Education, 27(1), 10-20.

Babamohamadi, H., Sotodehasl, N., Koenig, H. G., Al Zaben, F., Jahani, C., \& Ghorbani, R. (2017). The effect of Holy Qur'an recitation on depressive symptoms in hemodialysis patients: A randomized clinical trial. Journal of Religion and Health, 56 (1), 345-354.

Bukhori, M. bin I. bin M. Al. (1992). Shahih Al Bukhari. Beirut Libanon: Darul Qurub.

Capobianco, B. M., \& Feldman, A. (2006). Promoting quality for teacher action research: lessons learned from science teachers' action research. Educational Action Research, 14(4), 497-512.

https://doi.org/10.1080/096507906009 75668

Castle, K. (2006). Autonomy through pedagogical research. Teaching and Teacher Education, 22 (8), 1094-1 103.

Clarke, D., \& Hollingsworth, H. (2002). Elaborating a model of teacher professional growth. Teaching and Teacher Education, 18(8), 947-967.

Creswell, J. W. (2002). Educational research: Planning, conducting, and evaluating quantitative. Prentice Hall
Upper Saddle River, NJ.

Darwis, R. S. (2016). Membangun Desain dan Model Action Research dalam Studi dan Aksi Pemberdayaan Masyarakat. KOMUNIKA, 10(1), 142153.

Departemen Agama, R. I. (2005). Al-Quran dan Terjemahannya" AlJumanatul'Ali. Bandung: CV Penerbit J-Art.

Fadhillah, H. (2016). Pengaruh Membaca Alquran Terhadap Kestabilan Emosi Siswa Kelas XI SMA IT Abu Bakar Yogyakarta. Jurnal Riset Mahasiswa Bimbingan Dan Konseling, 5(8).

Ghiasi, A., \& Keramat, A. (2018). The effect of listening to holy quran recitation on anxiety: A systematic review. Iranian Journal of Nursing and Midwifery Research, 23(6), 411.

Hanafiah, N., \& Suhana, C. (2009). Konsep strategi pembelajaran. Bandung: Refika Aditama.

Hanbal, A. I. (2001). Musnad al-Imam Ahmad ibn Hanbal. Beirut: Mu'assasah al-Risalah.

Husna, M. (2015). Hubungan Kemampuan Membaca Al-Qur'an dengan Prestasi Pendidikan Agama Islam Peserta Didik Kelas VII SMP Negeri 2 Sungguminasa Kabupaten Gowa. Universitas Islam Negeri Alauddin Makassar.

James, M., \& McCormick, R. (2009). Teachers learning how to learn. Teaching and Teacher Education, 25(7), 973-982.

Jefferson, R. N. (2014). Action Research: Theory and Applications. New Review of Academic Librarianship, 20(2), 91116. https://doi.org/10.1080/13614533.2014 .921536

Joyce, B. Weils, M. Calhoun, E. (1996). Models of Teaching. USA: Alyn and Bacon.

Katsir, I. (2000). Tafsir Ibnu Katsir. Mesir: Dar al Kutub.

Korthagen, F. A. J. (2010). Situated learning theory and the pedagogy of teacher education: Towards an integrative 
Tedi Supriyadi, J. Julia, Prana Dwija Iswara \& Ani Nur Aeni, Eradicating Al-Qur'an Illiteracy...

view of teacher behavior and teacher learning. Teaching and Teacher Education, 26 (1), 98-106.

Korthagen, F. A. J. (2007). In search of the essence of a good teacher: towards a more holistic approach in teacher education. 2002.

Mar'i, A. S. B. (2018). Using Multimedia Program in teaching Recitation of the Holy Qur'an among eighth Grade Students in Light of their Self-Efficacy and its Effectiveness of Learning Motivation. مجلة الجامعة الإسلامية للار/سات 26) التربوية والنفسية, 26 (4)

Messiou, K. (2018). Collaborative action research: facilitating inclusion in schools. Educational Action Research, $0(0)$, 1-13. https://doi.org/10.1080/09650792.2018 .1436081

Niemi, R. (2018). Five approaches to pedagogical action research. Educational Action Research, 0(0), 116.

https://doi.org/10.1080/09650792.2018 .1528876

Nisbet, J., \& Shucksmith, J. (2017). Learning strategies. Routledge.

Novak, J. D., \& Gowin, D. B. (1984). Learning how to learn. Cambridge University Press.

Nurzaman, I. (2014). Efektivitas Penggunaan Metode Bil Hikmah Terhadap Tingkat Kemampuan Membaca Al-Quran Anak Usia Dini. Tarbawy: Indonesian Journal of Islamic Education, 1 (1), 33-43.

Olson, M. R., \& Craig, C. J. (2001). Opportunities and challenges in the development of teachers' knowledge: The development of narrative authority through knowledge communities. Teaching and Teacher Education, 17(6), 667684.

Penlington, C. (2008). Dialogue as a catalyst for teacher change: A conceptual analysis. Teaching and Teacher Education, 24 (5), 1304-1316.

Shihab, Q. (1992). Membumikan al-Quran, Fungsi dan Peran Wahyu dalam Kehidupan Masyarakat. Bandung:
Mizan.

Sophya, I. V. \& S. M. (2014). Metode Membaca Al-Qur'an. Elementary Islamic Techer Journal, 2 (2), 335-349.

Srijatun. (2017). Implementasi Pembelajaran Baca Tulis Al-Qur'an Dengan Metode laro Pada Anak Usia Dini Di RA Perwanida Slawi Kabupaten Tegal. Nadwa, Jurnal Pendidikan Islam, XI(1), 25-40.

Supriyadi, T., \& Julia, J. (2019). The Problem of Students in Reading the Quran: A Reflective-Critical Treatment through Action Research. International Journal of Instruction, 12 (1).

Syaifullah, M. (2017). Penerapan Metode An-Nahdliyah dan Metode Iqro'dalam Kemampuan Membaca Al-qur'an. Jurnal Kajian Ilmu Pendidikan.

Yahya, W. (2010). Bil Hikmah (Metode Terpadu) Cepat Membaca Al-Qur'an Buku I. Bandung: Fakultas Dakwah UNISBA bekerja sama dengan Baitul Hikmah.

Zech, L. K., Gause-Vega, C. L., Bray, M. H., Secules, T., \& Goldman, S. R. (2000). Content-Based Collaborative Inquiry: A Professional Development Model for Sustaining Educational Reform. Educational Psychologist, 35(3), 207217. https://doi.org/10.1207/S15326985EP3 503_6 